\title{
Factors associated with epilepsy in children in Mexico: a case-control study
}

\author{
Ma. del Rosario Cruz-Cruz ${ }^{1}$ Jorge Gallardo-Elías ${ }^{1}$, Sergio Paredes-Solís ${ }^{2 *}$, José Legorreta-Soberanis², \\ Miguel Flores-Moreno ${ }^{2}$ and Neil Andersson 2,3 \\ ${ }^{1}$ Department of Clinical Pediatrics, Hospital General Regional No. 1 Vicente Guerrero, Acapulco, Guerrero, Mexico; ${ }^{2}$ Tropical Diseases Research \\ Center (CIET), Universidad Autónoma de Guerrero, Acapulco, Guerrero, Mexico; ${ }^{3}$ Department of Familiy Medicine, McGill University, Montreal, Canada
}

\begin{abstract}
Background: Epilepsy is the most common chronic neurological disease in the world. In Mexico, epilepsy is among the diseases more related to mortality due to non-infectious causes in children. The objective of the study was to identify the factors associated with epilepsy in children entitled to the Mexican Social Security Institute (IMSS), in Acapulco, Mexico. Methods: We carried out a case-control study from April 2010 to April 2011. We selected 118 cases from the database of outpatient pediatric neurology with epilepsy with less than two years from the diagnosis using the International League Against Epilepsy criteria. We selected 118 controls from the same Medical Units where cases were detected. Data collected throughout a mother's interview included information on family history of epilepsy, prenatal, perinatal and postnatal history. Bivariate and multivariate analyses were performed using Mantel-Haenszel process. Results: Multivariate analysis identified three factors associated with epilepsy: family history of epilepsy in first-degree relatives (adjusted Odds ratio (aOR) 2.44, $95 \% \mathrm{Cl} 1.18$-5.03), birth asphyxia (aOR 2.20,95\% Cl 1.16-34.18), and urinary tract infection during pregnancy (aOR, 1.80 , $95 \% \mathrm{Cl} 1.0$ - 3.24). Conclusions: Preventing birth asphyxia and urinary tract infections during pregnancy reduces the risk of epilepsy regardless of the history of epilepsy in first-degree relatives.
\end{abstract}

Key words: Epilepsy. Child. Factors associated. Mexico.

\section{Factores asociados a epilepsia en niños en México: un estudio caso-control}

\section{Resumen}

Introducción: La epilepsia es la enfermedad neurológica crónica más común en el mundo. En México es considerada dentro de las principales enfermedades vinculadas a la mortalidad por enfermedades no infecciosas de la población infantil. El objetivo del estudio fue identificar los factores asociados a epilepsia en niños derechohabientes del Instituto Mexicano del Seguro Social (IMSS), en Acapulco, México. Métodos: Estudio de casos y controles realizado entre abril de 2010 y abril de 2011. Fueron seleccionados 118 casos de la consulta externa de neurología pediátrica, con criterios diagnósticos de epilepsia de acuerdo a la Liga Internacional Contra la Epilepsia, con máximo dos años de evolución. Los controles fueron seleccionados de las Unidades de Medicina Familiar de donde procedieron los casos. En una encuesta a las madres, se obtuvo información sobre antecedentes heredofamiliares, prenatales, perinatales y posnatales. El análisis bivariado y multivariado fue

Correspondence:

*Sergio Paredes-Solís

E-mail: sparedes@ ciet.org

2444-3409/@ 2018. Hospital Infantil de México Federico Gómez, published by Permanyer México SA de CV, all rights reserved.
Available online: 18-06-2018 Bol Med Hosp Infant Mex. 2017:74:334-340

www.bmhim.com 
mediante el procedimiento de Mantel-Haenszel. Resultados: Tres factores estuvieron asociados con la epilepsia: el antecedente familiar de epilepsia en familiares de primer grado (Razón de Momios ajustada (RMa) 2.44, IC95\% 1.18 -5.03), la asfixia al nacimiento (RMa 2.20, IC95\% 1.16-34.18) y la infección de la vía urinaria en la etapa prenatal (RMa, 1.80 IC95\% 1.0 3.24). Conclusiones: La asfixia al nacimiento y el reporte de infecciones de vías urinarias durante la gestación fueron factores asociados a epilepsia independientemente del antecedente de epilepsia en familiares de primer grado.

Palabras clave: Epilepsia. Niños. Factores asociados. México.

\section{Introduction}

Epilepsy is the most common chronic neurologic disease. According to the World Health Organization ${ }^{1}$, there are 50 million people affected worldwide. Incidence in developed countries ranges between 42 and 61 per 100,000 inhabitants2; this figure doubles in developing countries. Epilepsy affects all age groups with a greater incidence in children ${ }^{3}$. In Mexico, the estimated prevalence ranges between 349 to 680 per 100,000 inhabitants in the general population ${ }^{4,5}$, and between 180 to 400 per 100,000 inhabitants in children $^{6}$. Epilepsy is among the main diseases related to mortality due to non-infectious diseases in children in Mexico?.

In 2005, the International League Against Epilepsy (ILAE), defined as a practical criterion to diagnose epilepsy, two unprovoked seizures with more than 24 hours apart $^{8}$. In 2014, the ILAE included conditions such as repeated seizures in more than 24 hours, recurrent seizures in up to a ten-year period and epileptic syndrome $^{8,9}$.

The greatest frequency of epilepsy is in the pediatric age, and males are the most affected ${ }^{10}$. In Mexico, 400 to 800 new cases per 100,000 children are reported each year ${ }^{11}$. Epilepsy pathogenesis can be genetic or acquired $^{12}$. Genetic abnormalities contribute to the development of acquired epilepsy by increasing a person's predisposition of having seizures triggered by environmental factors ${ }^{13,14}$.

Epilepsy has a high level of familial aggregation ${ }^{15,16}$,with a multifactorial hereditary pattern ${ }^{17,18}$. Environmental risk factors can act synergistically for its development in genetically susceptible patients ${ }^{19}$. Of the environmental factors, prenatal and perinata ${ }^{20}$-which include preeclampsia, asphyxia at birth ${ }^{21}$ and their complications in the newborn's central nervous system-, are associated with a higher frequency of epilepsy ${ }^{22,23}$. Infections of the urinary and respiratory tract ${ }^{24,25}$, and vaginal infections during the prenatal period have been associated with a greater risk of epilepsy ${ }^{26}$.
In Mexico, the few published clinical research articles about epilepsy are descriptive, and we did not find any that estimated the association between genetic and environmental factors and epilepsy ${ }^{10,11}$. The objective of this study was to identify epilepsy associated factors in children entitled to the Mexican Social Security Institute (IMSS for its Spanish acronym), in Acapulco, Mexico.

\section{Methods}

A case-control study was conducted in patients from the Pediatric Neurology Service of the Hospital General Regional No.1 Vicente Guerrero dependent on the Mexican National Institute of Social Security in Acapulco, Mexico. The hospital attends to patients referred from first-level units, the cases and controls are representative of a population of IMSS's beneficiaries of Acapulco. The search for cases and controls was conducted between April 2010 and April 2011.

Cases were selected from the database of the outpatient clinic of the Pediatric Neurology Service. Each case had a control selected from the same medical unit where the cases were referred, to guarantee that the subject came from the same source population. Cases were selected based on a recent diagnosis of epilepsy, with less than two years from the diagnosis, using the criteria from the ILAE that were valid during the study period: two or more unprovoked seizures with less than 24 hours apart. Acute symptomatic crises, single seizures, and childhood febrile seizures were excluded.

Definition of epilepsy case: a patient older than 28 days and younger than 15 years of age, with diagnosis of epilepsy based on the ILAE classification, with less than two years from the diagnosis, and living in Acapulco, Guerrero.

Definition of control: patient older than 28 days and younger than 15 years of age, without a diagnosis of epilepsy, paired by age, gender, and ascription of the same Family Unit of a case, and living in Acapulco, Guerrero. 
Information about cases and controls was obtained through an interview with the patient's mother and the corresponding clinical record. After obtaining written informed consent from one of the parents, a questionnaire was applied by qualified personnel. The measuring instrument was validated by a set of experts including a pediatric neurologist, a pediatrician, and an epidemiologist ${ }^{27}$.

The variables included in the study were: patient's age and gender; family history of epilepsy in first-grade relatives. A history of epilepsy in the parents, siblings, and grandparents; a history of urinary tract infection (UTI) during pregnancy (a case was recorded as an UTI if an affirmative response to the question was "Did you had an UTI during your pregnancy?" was obtained from the mother). Also, a clinical picture compatible with preeclampsia and eclampsia according to the patient's age, type of delivery, gestational age, weight at birth, and a history of asphyxia at birth. The concept of asphyxia at birth in this study relates to the inability of the child to initiate or sustain adequate spontaneous breathing at the time of birth, assessed with the question "your child's crying was strong, weak, or absent?" Relevant post-natal information included a history of traumatic brain injury or infections of the central nervous system. Data were complemented with social and academic information of the family such as patient's scholarship, academic performance, teacher's acceptance, classmates, family and parent's support.

From the clinical records, the following data were collected: type of epilepsy, interpretation of the electroencephalogram and head axial computed tomography, and treatment. Epilepsy was considered to be active when the patient had uncontrolled epileptic seizures during the period of study or when epileptic crises were controlled, but with ongoing treatment.

Data were captured twice with the program EpiData version $3.1^{28}$ and were validated using the tool Validate of the same program to avoid obvious typing errors. The analyze was conducted with the statistical package CIETmap ${ }^{29}$. Using the Mantel-Haenszel process, odds ratios (OR) of the variables included in the bivariate and multivariate analysis were calculated along with the 95\% confidence interval level $(\mathrm{Cl} 95 \%)^{30}$. Multivariate analysis began with a saturated model, that included the variables that reached statistical significance, adjusting for the variables "premature birth" and "urinary tract infection during pregnancy", and excluding factors that did not maintain statistical significance $(p<0.05)$ one by one, until the final model was chosen.
The protocol was registered and authorized by the Local Research Committee № 1102 of the HGR N ${ }^{\circ} 1$ with the registration number 2009 1102-18. Patients' names were kept anonymous and were only used to identify their clinical record.

\section{Results}

A total of 118 cases and 118 controls were included. Gender distribution was very similar in both groups of patients, $55 \%(n=65)$ males and $45 \%(n=53)$ of females in the case group; $56 \%(n=66)$ males and $44 \%(n=52)$ females in the control group. There was a greater proportion $(20 \%, 24 / 118)$ of cases with a family history of epilepsy compared to control patients (10\%, 12/118). Urinary tract infection during the mother's pregnancy was greater in the cases $(33 \%, 39 / 118)$ compared to controls $(22 \%, 26 / 118)$. A greater prevalence of asphyxia at birth was referred by the mothers in the case group $(28 \%, 33 / 118)$, than in the control group $(15 \%, 18 / 118)$.

\section{Characterization of epilepsy cases}

Fifty-four percent of the cases were males; age groups had the following distribution: younger than five years, $35 \%, 6$ to 10 years, $40 \%$; and 11 to 15 years, $25 \%$. In 78 of the 118 cases (66\%) the type of epilepsy was idiopathic, 40 cases correspond to the symptomatic form (345). Generalized seizures were the most frequent (86\%; 101/118).

Every case had an electroencephalogram, and 115 cases had a simple and contrast-enhanced computed axial tomography (CT). Moderate to severe cortical and cortico-subcortical atrophy was reported in 44 cases (38\%); 68 head CTs were reported as normal $(59 \%)$ and three with other anomalies $(2.6 \%)$. There were 32 cases with psychomotor retardation (27\%) and seven patients with a subnormal intellectual coefficient (6\%). Five patients had attention disorders (4\%) and four cases language delay (3\%).

Regarding social aspects, $6 \%(5 / 87)$ of the cases reported problems for school admission with school principals, teachers, and one parent. There was rejection in their family environment and neighborhoods due to epilepsy status in $7 \%(8 / 118)$, and $34 \%(40 / 118)$ of the mothers had no support by the father of the patient. Seventy-three percent of the cases attended school $(n=87)$, of which $43 \%(38 / 87)$ have an acceptable academic performance. 
Table 1. Bivariate analysis of factors associated with epilepsy in Acapulco, Mexico, 2010-2011

\begin{tabular}{|c|c|c|c|c|}
\hline Factor & Cases & Controls & uaOR & C195\% \\
\hline $\begin{array}{l}\text { Prenatal care } \\
\text { Yes } \\
\text { No }\end{array}$ & $\begin{array}{c}109 \\
9\end{array}$ & $\begin{array}{c}112 \\
6\end{array}$ & 0.65 & $0.22-1.88$ \\
\hline $\begin{array}{l}\text { Family history of epilepsy } \\
\text { Yes } \\
\text { No }\end{array}$ & $\begin{array}{l}23 \\
95\end{array}$ & $\begin{array}{c}13 \\
105\end{array}$ & 2.1 & $1.08-4.48$ \\
\hline $\begin{array}{l}\text { Urinary tract infection } \\
\text { Yes } \\
\text { No }\end{array}$ & $\begin{array}{l}39 \\
79\end{array}$ & $\begin{array}{l}26 \\
92\end{array}$ & 1.75 & $0.98-3.11$ \\
\hline $\begin{array}{l}\text { Diarrheal disease } \\
\text { Yes } \\
\text { No }\end{array}$ & $\begin{array}{c}2 \\
116\end{array}$ & $\begin{array}{c}2 \\
116\end{array}$ & 1.0 & $0.14-7-13$ \\
\hline $\begin{array}{l}\text { Airway infections } \\
\text { Yes } \\
\text { No }\end{array}$ & $\begin{array}{l}28 \\
90\end{array}$ & $\begin{array}{l}26 \\
92\end{array}$ & 1.10 & $0.60-2.03$ \\
\hline $\begin{array}{l}\text { Preeclampsia } \\
\text { Yes } \\
\text { No }\end{array}$ & $\begin{array}{l}20 \\
98\end{array}$ & $\begin{array}{l}24 \\
94\end{array}$ & 0.79 & $0.41-1.53$ \\
\hline $\begin{array}{l}\text { Eclampsia } \\
\text { Yes } \\
\text { No }\end{array}$ & $\begin{array}{c}1 \\
117\end{array}$ & $\begin{array}{c}1 \\
117\end{array}$ & 1.0 & $0.16-16$ \\
\hline $\begin{array}{l}\text { Asphyxia at birth } \\
\text { Yes } \\
\text { No }\end{array}$ & $\begin{array}{l}33 \\
85\end{array}$ & $\begin{array}{c}18 \\
100\end{array}$ & 2.15 & $1.14-4-07$ \\
\hline $\begin{array}{l}\text { Premature birth } \\
\text { Yes } \\
\text { No }\end{array}$ & $\begin{array}{c}13 \\
105\end{array}$ & $\begin{array}{c}8 \\
110\end{array}$ & 1.70 & $0.68-4.25$ \\
\hline $\begin{array}{l}\text { Birth by caesarean section } \\
\text { Yes } \\
\text { No }\end{array}$ & $\begin{array}{l}69 \\
50\end{array}$ & $\begin{array}{l}78 \\
41\end{array}$ & 0.73 & $0.43-1.23$ \\
\hline
\end{tabular}

*uaOR, unadjusted Odds Ratio; CI95\%, 95\% confidence interval

\section{Factors associated with epilepsy}

Table 1 shows an estimation of the association (unadjusted OR) of the relevant variables in the study to epilepsy. A family history of a first-grade relative with epilepsy and a history of asphyxia at birth were significantly associated with epilepsy. Urinary tract infection during the mother's pregnancy had a marginal significance.

The final model for the multivariate analysis using adjusted estimations (aOR) for the association of the variables with epilepsy is shown in table 2 . Three factors with an independent effect remained in the final model: a history of a first-grade relative with epilepsy (aOR 2.44, CI95\% 1.18-5.03), asphyxia at birth (aOR 2.20, Cl95\% 1.16-4.18) and urinary tract infection during pregnancy (aOR: 1.80, Cl95\% 1.0-3.24). The final model was adjusted for premature birth.

\section{Discussion}

Cases with a recent diagnosis of epilepsy, with less than two years from the diagnosis, were recruited during April 2010 to April 2011, based on the practical diagnosis criteria for epilepsy by the ILAE that were valid at that time. Recently, ILAE has extended their criteria to increase sensitivity for the diagnosis of epilepsy ${ }^{8,9}$. We consider that patients included in our study would be classified as epilepsy cases, given that the current criterion does not exclude the previous. The two-year period was chosen with the goal of reducing recall bias.

The relationship between a family history of epilepsy and the incidence of the disease has already been reported in other studies ${ }^{15,17,18}$. We only inquired about a history of epilepsy in first-grade relatives, 
Table 2. Final model from the multivariate analysis using epilepsy and associated factors in a pediatric population from IMSS in Acapulco, Mexico, 2010

\begin{tabular}{|l|c|c|c|c|c|}
\hline Factor & uaOR & aOR & Cl95\%a & $X^{2 h e t}$ & $\mathbf{p}$ \\
\hline Family history of epilepsy & 2.26 & 2.44 & $1.18-5-03$ & 2.85 & 0.41 \\
\hline Asphyxia at birth & 2.07 & 2.20 & $1.16-4.18$ & 2.43 & 0.48 \\
\hline Urinary tract infections & 1.75 & 1.80 & $1.0-3.34$ & 1.24 & 0.74 \\
\hline
\end{tabular}

*uaOR, unadjusted Odds Ratio; aOR, adjusted Odds Ratio; CI95\%, 95\% confidence interval for the aOR; $X^{2 h e t}$. Chi square for heterogeneity to assess effect modification; $p=p$ value for the Chi square for heterogeneity

even so, recall bias cannot be discarded. Epilepsy has a high level of familial aggregation; Asadi-Pooya found that a family history of epilepsy increased risk by 3.3 , which was discretely superior to the one found in our study ${ }^{16}$. Cansu et al. ${ }^{21}$, in Turkey, found that a family history increased risk by 6.4 and Hunza et al. ${ }^{18}$, in the United Arab Emirates reported an increased risk of 17.7, a stronger association than the one reported in our study ${ }^{21}$.

Epilepsy does not follow a classic Mendelian inheritance pattern; there is a risk of acquiring it with a multifactorial pattern, where the environment seems to have a great influence. The existence of genes that confer a greater risk of developing idiopathic or symptomatic epilepsy has been already documented. Nevertheless, these genes by themselves do not explain the probability of having the disease, since penetrance is usually reduced and environmental factors are frequently unknown ${ }^{12}$. External factors, whether environmental or due to de novo spontaneous mutations, increase the susceptibility of having an epilepsy syndrome. The environmental susceptibility promotes the manifestation of epilepsy ${ }^{31}$.

Asphyxia at birth was significantly associated with epilepsy; we recognize that the parameter used to measure asphyxia in our study was not ideal. However, we consider it to be a good approximation since it is the only sign that is used to begin cardiopulmonary resuscitation in the newborn according to the guidelines for Cardiopulmonary Resuscitation and Emergency Cardiovascular Care in Neonates from the American Pediatric Association and the American Heart Association $(\mathrm{AHA})^{31}$. Our findings are compatible with those documented by other studies dealing with asphyxia at birth and epilepsy ${ }^{32}$.

Edwards et al., in Kenia, reported that children with difficulty breathing at birth increased their risk of active epilepsy by 5.7 times $^{20}$. Daoud et al., in Jordan ${ }^{33}$, found that newborns with an Apgar score $<3$ at 5 minutes, had 3.2 times higher risk of epilepsy compared with children with a greater Apgar.

Asphyxia at birth can lead to an important number of deaths and leaves a similar number of survivors with long-term sequelae such as cerebral palsy, learning disorders, epilepsy and other developmental issues ${ }^{26}$. Derived from cerebral ischemia, normal development of central nervous system structures and organization of its functions can interrupt the sequence of events which characterize development and determine the occurrence of a neurological disorder with its different severities and manifestations, such as cortical, subcortical or cortico-subcortical atrophy, which are highly epileptogenic lesions ${ }^{23}$. Asphyxia at birth is a factor that can be preventable by close surveillance of labor and delivery ${ }^{32}$.

Among the prenatal factors, an association between a history of urinary tract infection and epilepsy was found. In our study, the association with this factor had a marginal significance; it was included in the saturated model for the multivariate analysis to adjust for other factors and discard it as a confounding factor or an effect modifier. The relationship between urinary tract infection during pregnancy and epilepsy remained in the final model of the multivariate analysis. The multivariate analysis was adjusted to a history of premature birth without other factors changing its independent effect.

Several studies have associated urinary tract infection during pregnancy with an increased risk of epilepsy ${ }^{24,25}$. McDermott et al. found that children of women that had a urinary tract infection during pregnancy had a greater risk (1.27) of having epilepsy; this increased (2.56) if the mother also had epilepsy ${ }^{24}$. Sun et al. also reported the association between urinary tract infection and risk of epilepsy: those exposed to cystitis of the mother had 1.4 times the risk of having epilepsy, the risk was greater (2.3) in those exposed to 
pyelonephritis of the mother during the prenatal pe$\operatorname{riod}^{25}$. Our study did not evaluate the possible synergy of having a family history of epilepsy and urinary tract infection during pregnancy, the part of the urinary tract that was affected was not specifically identified, nor was the infectious agent, or the trimester when the UTI occurred, which should be explored in future studies.

During pregnancy, there are physiological changes in innate and adaptive immunity to avoid pregnancy rejection and that, associated with poor nutritional status, lead to a greater risk of infections. Nutrients play a very important role in the immunologic defense mechanisms of humans; they exert immunomodulatory effects and influence host susceptibility to infections ${ }^{19}$. Health promotion during prenatal care must ensure an optimal state of health and nutrition to carry a healthy pregnancy.

This study identified three factors associated with epilepsy in IMSS beneficiaries in Acapulco. It is possible that the size of the study ( $n=118$ with their respective controls) was insufficient to detect associations with other factors.

Epilepsy results from multifactorial interactions and synergies ${ }^{33}$ and our study represent a modest approach to the complexity and size of this health issue.

Our study has other limitations that should be considered when evaluating the scope of the results. First, the source of information, since data was provided by the patients' mothers. Ideally, data should come from the clinical records where pregnancy and birth of the subjects were registered. There was difficulty obtaining all the clinical records for two main reasons: 1) at the moment of pregnancy or birth they were not IMSS beneficiaries, or 2) some records were discarded since they are only kept active for ten years.

Another limitation was the way asphyxia at birth and UTI were assessed. Most mothers did not remember the Apgar score at birth—they are rarely provided with this information-so we used the child's crying at birth as a proxy variable. There was no confirmation of urinary tract infection during pregnancy through the clinical record and UTI were considered if reported by the mother. Relatives with epilepsy were not specifically identified, nor was it asked about medications used in case the mother had epilepsy which could also be among the possible risk factors associated with epilepsy. Of this report, apparently the first of its type in Mexico, other lines of research may be derived that could contribute to the issue of epilepsy in Mexico.

Regarding the description of the cases, $54 \%$ were males, idiopathic epilepsy and generalized seizures were the most frequent forms; these results are similar to those previously reported ${ }^{10,11}$.

Concerning the social aspects, the cases reported issues with the parents, with school admission, their principals and their teachers, which was similar to a report by Aguilar-Rebolledo et al. ${ }^{34}$. Ignorance of the disease and social stigma around epilepsy are factors that are associated with his latter result. Patients were rejected by their family and in their neighborhood, and a third of the patients' mothers did not have the support of the patient's father. Similar to what has been documented by Figueroa, in our study, epilepsy is a burden that falls mainly on the mothers; the impact of this disease reflects on the patient, his family, and their social context ${ }^{35}$.

So far, genetic factors are not modifiable to reduce the incidence of epilepsy, but prenatal and perinatal risk factors are. This study identified two specific potential factors: asphyxia at birth and urinary tract infection during pregnancy, which can be the target of actions to prevent epilepsy.

\section{Ethical disclosures}

Protection of human and animal subjects. The authors declare that no experiments were performed on humans or animals for this study.

Confidentiality of data. The authors declare that they have followed the protocols of their work center on the publication of patient data.

Right to privacy and informed consent. The authors declare that no patient data appear in this article.

\section{Conflicts of interest}

The authors declare no conflicts of interest.

\section{References}

1. World Health Organization (WHO). Epilepsy: epidemiology, aetiology and prognosis. 2012; Fact sheet No. 999. Geneva, Switzerland. Available at: http://www.who.int/mediacentre/factsheets/fs999/en.

2. Hauser W A, Beghi E. First seizure definitions and worldwide incidence and mortality. Epilepsia 2008;49:8-12.

3. Kotsopoulos, AWI, Van Merode T, Kessels GHF, De Krom CTFM, Knottnerus JA. Systematic review and meta-analysis of incidence studies of epilepsy and unprovoked seizures. Epilepsia 2002;43:1402-9.

4. Olivares L, Barriga R, Camacho R, Trachonis M. La epilepsia en México. Salud Pub Mex. 1972;14:365-71.

5. Cruz-Alcalá LE, Vázquez-Castellanos JL. Prevalencia de algunas enfermedades neurológicas en la Ciudad de Tepatitlán, Jalisco, México. Rev Mex Neuroci. 2002;3:71-6.

6. Gutiérrez-Ávila JH . Prevalencia de la epilepsia infantil en una población rural de México. Salud Pub Mex. 1980;22:279-3.

7. Fernández-Cantón S, Hernández-Martínez A M. Mortalidad en menores de 15 años por enfermedades no transmisibles. México, 2000-2014. Bol Med Hosp Infant Mex. 2015;72:80-3.

8. Fisher RS, Acevedo C, Arzimanoglou A, Bogacz A, Cross JH, Elger CE, et al. ILAE official report: a practical clinical definition of epilepsy. Epilepsia. 2014 Apr;55(4):475-82. doi: 10.1111/epi.12550. Epub 2014 Apr 14. 
9. Fisher RS, van Emde Boas W, Blume W, Elger C, Genton P, Lee P, et al Epileptic seizures and epilepsy: definitions proposed by the International League Against Epilepsy (ILAE) and the International Bureau for Epilepsy (IBE). Epilepsia 2005;46:470-2

10. Soto-Chávez V, Ceja-Moreno H, Soto-Mancilla JL, Pérez R D. Perfil epidemiológico de los niños con epilepsia. Arch Invest Pediatr Mex. 2003 3:395-400.

11. Serrano-Martín J. Aspectos epidemiológicos de la epilepsia en un Hospital General de Segundo Nivel. Plast Rest Neurol. 2004;3:39-43.

12. Armijo J, Valdizan M, de las Cuevas I, Cuadrado A. Avances en la fisiopatología de la epileptogénesis: aspectos moleculares. Rev Neurol 2002; 34:409-29.

13. Arcos B, Palacios L, Mora O, Sánchez J, Jiménez M, Jiménez I. Aspectos genéticos de la susceptibilidad a desarrollar epilepsia idiopática. Rev Neurol. 2000;30:173-7.

14. Solano A, Playán A, López-Pérez MJ, Montoya J. Enfermedades genéticas del ADN mitocondrial humano. Salud Pub Mex. 2001;43:151-61.

15. Ottman R, Annegers JF, Hauser WA, Kurland LT. Seizure risk in offspring of parents with generalized versus partial epilepsy. Epilepsia. 1989; 30:157-61.

16. Asadi-Pooya AA, Hojabri K. Risk factors for childhood epilepsy: a casecontrol study. Epilepsy Behav. 2005;6:203-6.

17. Cabrera M. Clinical expression and evolution of epilepsy in consanguineous families in a reserved community in the Paraguayan Chaco. An Fac Cienc Med. 2005;38:1-12.

18. Hunza K, Abeer M, Zina-Al-Sakini, Zulfiquar K, Sohail A, Shaikh R B et al. Consanguinity, family history and risk of epilepsy: A case contro study. Gulf Medical Journal. 2012;1:32-6.

19. Huseyinoglu N, Ozben S, Arhan E, Palanci Y, Gunes N. Prevalence and risk factors of epilepsy among school children in Eastern Turkey. Pediatr Neurol. 2012;47:13-8.

20. Edwards T, Scott A G, Munyoki G, Odera V M, Chengo E, Bauni E, et al Active convulsive epilepsy in a rural district of Kenya: a study of prevalence and possible risk factors. Lancet Neurol. 2008;7:50-6.

21. Cansu A, Serdaroğlu A, Yüksel D, Doğan V, Ozcan S, Hirfanoğlu T, et al. Prevalence of some risk factors in children with epilepsy compared to their controls. Seizure. 2007;16:338-44

22. Rodríguez M, Quispe Z, Sifuentes M. Factores de riesgo en epilepsia secundaria en niños. Rev Neuropsiq. 2002;65:136-41.
23. Murguía-de Sierra MT, Lozano R, Santos Jl. Mortalidad perinatal por asfixia en México: problema prioritario de salud pública por resolver. Bol Med Hosp Infant Mex. 2005;62:375-83.

24. McDermott S, Mann J R, Wu J. Maternal genitourinary infection appears to synergistically increase the risk of epilepsy in children of women with epilepsy. Neuroepidemiol. 2009;34:117-22.

25. Sun Y, Vestergaard M, Christensen J, Nahmias AJ, Olsen J. Prenatal exposure to maternal infections and epilepsy in childhood: a population-based cohort study. Pediatrics. 2008;121:e1100-7.

26. Wu CS, Pedersen LH, Miller JE, Sun Y, Streja E, Uldall P, et al. Risk of cerebral palsy and childhood epilepsy related to infections before or during pregnancy. PLoS One. 2013;8:e57552.

27. Escobar-Pérez J, Cuervo-Martínez A. Validez de contenido y juicio de expertos: una aproximación a su utilización. Avances Medición. 2008; 6:27-36.

28. Lauritsen JM, BruusM. EpiData(version). A comprehensive tool for validated entry and documentation of data. Odense: The EpiData Association; 2003-2005.

29. Andersson N, Mitchell S. CIETmap: Free GIS and epidemiology software from the CIETgroup, helping to build the community voice into planning. Montreal: World Congress of Epidemiology; 2002

30. Mantel N, Haenszel W. Statistical aspects of the analysis of data from retrospective studies of disease. J Natl Cancer Inst. 1959;22:719-48.

31. Asociación Americana de Pediatría y la Asociación Americana de Corazón (AHA). Guía para la Reanimación Cardiovascular y Atención Cardiovascular de Emergencia para el Neonato. Circulation. 2010;122:S909-91.

32. Ngugi A K, Bottomley C, Kleinschmidt I, Wagner R G, Kakooza-Mwesige A, Ae-Ngibise K, et al. Prevalence of active convulsive epilepsy in sub-Saharan Africa and associated risk factors: cross-sectional and case-control studies. Lancet Neurol. 2013;12:253-63.

33. Daoud AS, Batieha A, Bashtawi M, El-Shanti H. Risk factors for childhood epilepsy: a case-control study from Irbid, Jordan. Seizure. 2003;12: 171-4.

34. Aguilar-Rebolledo F, Rayo-Mares D, Zanabria-Salcedo M. Problemas psicosociales de los niños con epilepsia en México. Plast Rest Neurol. 2003;2:103-8

35. Figueroa-Duarte AS. Estudio clínico, epidemiológico y sociocultural de la epilepsia. Un enfoque crítico. Arch Neurocien (Mex). 2010;15:139-51. 